\title{
Appearance of an arginine vasotocin receptor of large molecular size in the uterus (shell gland) of the hen at oviposition
}

\author{
T. Takahashi ${ }^{I}$, M. Kawashima ${ }^{\text {* }}$, T. Yasuoka ${ }^{2}$ and K. Tanaka ${ }^{3}$ \\ ${ }^{1}$ Department of Biological Diversity and Resources, Gifu University, Yanagido, Gifu 501-11; ${ }^{2}$ Department \\ of Oral and Maxillofacial Surgery, Gifu University School of Medicine, Tsukasamachi, Gifu 500; and \\ ${ }^{3}$ Department of Zootechnical Science, Tokyo University of Agriculture, Sakuragaoka, Setagaya-ku, \\ Tokyo 156, Japan
}

\begin{abstract}
The molecular mass of the arginine vasotocin receptor in membrane fractions of the uterus (shell gland) of hens was estimated by autoradiography of $\left[{ }^{125} \mathrm{I}\right]$-labelled arginine vasotocin binding protein after SDS-PAGE. A band of approximately $67 \mathrm{kDa}$ was found in all of the samples taken from laying hens before and after oviposition and from nonlaying hens. In addition to this band, another band of approximately $95 \mathrm{kDa}$ was found in samples from laying hens taken immediately before and after oviposition. Both bands were reduced by the presence of unlabelled arginine vasotocin or mesotocin, but the reduction was greater by arginine vasotocin than by mesotocin. These two bands were not reduced by chicken luteinizing hormone-releasing hormone-I $\left(\mathrm{Gln}^{8}-\mathrm{GnRH}\right)$, chicken luteinizing hormonereleasing hormone-II $\left(\mathrm{His}^{5}, \operatorname{Trp}^{7}, \mathrm{Tyr}^{8}-\mathrm{GnRH}\right)$ and chicken angiotensin-II ( $\mathrm{Val}^{5}$-angiotensinII). The appearance of the arginine vasotocin receptor of the larger molecular size may be related to oviposition in hens.
\end{abstract}

\section{Introduction}

The avian neurohypophysial hormone, arginine vasotocin (AVT) induces oviposition (expulsion of egg) (Rzasa and Ewy, 1970) by causing the contraction of the uterus (shell gland) in the hen (Munsick et al, 1960). The presence of a receptor for AVT in the uterus of the hen was demonstrated by Takahashi et al. (1992), and the AVT receptor binding affinity increases and capacity decreases at the time of oviposition (Takahashi et al., 1994). However, the cause of the increase in the binding affinity of the receptor has not been elucidated. Brennan (1988) reported that the binding affinity of the insulin receptor in the brain of rats changes together with a change in the molecular size of the receptor during fetal development in the uterus. The present study was performed to determine whether the AVT receptor of the hen uterus changes at the time of oviposition.

\section{Materials and Methods}

Animals and tissue preparations

White Leghorn hens (18-24 months of age; $1.8-2.2 \mathrm{~kg}$ body weight), kept under a lighting regimen of $14 \mathrm{~h}$ light (05:00-19:00 h) per day with feed and water provided ad libitum, were used. Uterine myometrial tissues were obtained from laying hens at four different times: $3 \mathrm{~h}$ before, within $5 \mathrm{~min}$ before, within $5 \mathrm{~min}$ after, and $1 \mathrm{~h}$ after oviposition of the first egg of a sequence occurring at about 07:00 h. At each time, four hens were served. The tissues were also

*Correspondence. obtained from four nonlaying hens that had not laid an egg for at least 10 days. In the nonlaying hens, the ovarian mass was less than $8.8 \mathrm{~g}$ and the oviduct mass was less than $11.2 \mathrm{~g}$. The serum concentrations of progesterone and oestradiol, as measured by radioimmunoassay (Shodono et al., 1975), were $312 \pm 13 \mathrm{pmol} \mathrm{I}^{-1}(n=51)$ and $294 \pm 12 \mathrm{pmol} \mathrm{l}^{-1}(n=51)$, respectively. Membrane fractions of the tissues were prepared by the method reported by Takahashi et al. (1992). Protein concentrations of the fractions were determined by the method of Lowry et al. (1951) using BSA (fraction V; Seikagaku Kogyo Co., Ltd, Tokyo) as the standard.

\section{${ }^{125}$ I]-labelled AVT binding and cross-linking}

AVT (Bachem Inc., Torrance, CA) was labelled with ${ }^{125}$ I by the use of Iodogen ${ }^{\mathbb{B}}$ (Sigma Chem. Co., St Louis, MO). The specific activity of the [ ${ }^{125} \mathrm{I}$-labelled AVT was $1877 \mathrm{Ci}$ $\mathrm{mmol}^{-1}$. Methods used for labelling and the determination of specific activity were described by Takahashi et al. (1992). The membrane fractions $(30 \mu \mathrm{g}$ per tube) were incubated at $30^{\circ} \mathrm{C}$ for $16 \mathrm{~h}$ with $1 \mathrm{nmol}\left[{ }^{125} \mathrm{I}\right]$-labelled AVT $1^{-1}$ in TE buffer $\left(50 \mathrm{mmol}\right.$ Tris- $\mathrm{HCl}^{-1}, 2$ mmol EDTA ${ }^{-1}, \mathrm{pH} \mathrm{7.4)}$ in the presence or absence of $10 \mu \mathrm{mol}$ unlabelled AVT $1^{-1}$, mesotocin (MT; Bachem), chicken (c) luteinizing hormonereleasing hormone-I (cLHRH-I; $\mathrm{Gln}^{8}-\mathrm{GnRH}$; Peninsula Lab., Inc., Belmont, CA) cLHRH-II ( $\mathrm{His}^{5}, \operatorname{Trp}^{7}, \mathrm{Tyr}^{8}-\mathrm{GnRH}$; Bachem) and cAngiotensin-II (Val ${ }^{5}$-angiotensin-II; Bachem) in a total volume of $300 \mu \mathrm{l}$. Bound $\left[{ }^{125} \mathrm{I}\right]$-labelled AVT was separated from free $\left.{ }^{125} \mathrm{I}\right]$-labeiled AVT by centrifugation (10000 $\mathrm{g}$, $10 \mathrm{~min}, 4^{\circ} \mathrm{C}$ ) and washed by the same centrifugation. The precipitate was suspended in $200 \mu \mathrm{l}$ TE buffer. Cross-linking of 
AVT receptor to the labelled AVT was carried out for $15 \mathrm{~min}$ at $4^{\circ} \mathrm{C}$ following the addition of $20 \mu \mathrm{l} 0.11 \mathrm{mmol}$ disuccinimidyl suberate $\mathrm{l}^{-1}$ (DSS; Pierce, Rockford, IL) dissolved freshly in dimethyl sulfoxide (Wako Pure Chemical Industries, Ltd, Osaka) (Brennan, 1988; Bruno and Berelowitz, 1989; Rosenfeld et al., 1989). The reaction was terminated by adding $280 \mu \mathrm{l}$ stop buffer (100 mmol Tris- $\mathrm{HCl} \mathrm{l}^{-1}$, $10 \mathrm{mmol}$ EDTA $1^{-1}, \mathrm{pH} \mathrm{7.4)}$ (Rosenfeld et al., 1989), and the mixture was centrifuged ( $10000 \mathrm{~g}, 10 \mathrm{~min}, 4^{\circ} \mathrm{C}$ ). The precipitate was suspended in $25 \mu \mathrm{l}$ of the sample buffer, $62.5 \mathrm{mmol}$ Tris- $\mathrm{HCl} \mathrm{l}{ }^{-1}$, $2 \%(\mathrm{w} / \mathrm{v})$ sodium dodecyl sulfate (SDS; Kishida Chemical Co., Ltd, Osaka), 1\% (v/v) Triton X-100 (Nacalai Tesque, Inc., Kyoto), 20\% glycerol, 0.01\% (w/v) bromophenol blue (BPB; Nacalai), pH 6.8, and shaken for $60 \mathrm{~min}$ at $4^{\circ} \mathrm{C}$ (Swedlund and Rosenzweig, 1990). After centrifugation (10 $000 \mathrm{~g}, 10 \mathrm{~min}$, $4^{\circ} \mathrm{C}$ ), the supernatant was subjected to the SDS-polyacrylamide gel electrophoresis (PAGE). Relative migrations of specific bands were not altered by the presence of 2-mercaptoethanol (Nacalai) at the concentration of $2 \%(\mathrm{v} / \mathrm{v})$ in the sample buffer.

\section{SDS-PAGE and autoradiography}

The SDS-PAGE was run with $15 \mathrm{~mA}$ for $1.5 \mathrm{~h}$ according to the method of Laemmli (1970) using 5-20\% gradient polyacrylamide slab gels ( $1 \mathrm{~mm}$ thickness, $70 \mathrm{~mm} \times 90 \mathrm{~mm}$; SPG-520L PAGEL ${ }^{(\mathrm{R})}$; Atto Corp., Tokyo). After the electrophoresis, the gel was soaked in $10 \%$ acetic acid for $30 \mathrm{~min}$. Both sides of the gels were covered with a polyester film (100 $\mu \mathrm{m}$ thickness), and the gels were placed under Imaging Plate (Fuji Photo Film Co., Ltd, Tokyo) (Sonoda et al., 1983; Amemiya and Miyahara, 1988) for $16 \mathrm{~h}$ at room temperature. The sensitivity of the Imaging Plate for the radiation from ${ }^{125} \mathrm{I}$ is known to be approximately 4000 times higher than usual $X$-ray films, and the photostimulated luminescence increases linearly with an increase in the radioactivity from 1 to 10000 d.p.m. mm ${ }^{-2}$ (Fuji Technical Information, 1993). Autoradiograms were obtained by the use of Fujix Bio-Imaging Analyzer (BAS2000; Fuji). The apparent molecular weight was determined by using the prestained protein molecular weight standards (Life Technologies, Inc., Gaithersburg, MD), lysozyme (MW: 15 550), $\beta$-lactoglobulin (MW: 18 200), carbonic anhydrase (MW: 28 050), ovalbumin (MW: 44350 ), BSA (MW: 71 150), phosphorylase B (MW: 112400 ) and myosin with H-chain (MW: 236 700).

\section{AVT receptor binding assay}

The binding assay used for the AVT receptor was reported by Takahashi et al. (1992). The equilibrium dissociation constant $\left(K_{\mathrm{d}}\right)$, an index of binding affinity, and the maximum binding capacity $\left(B_{\max }\right)$ were estimated by Scatchard analysis (Scatchard, 1949). The samples that were used for SDS-PAGE were also used in the binding assays. In each group of samples, four replicate determinations were performed.

\section{Statistical analyses}

Data were analysed by one-way ANOVA (Snedecor and Cochran, 1967). When a significant effect was found (a)

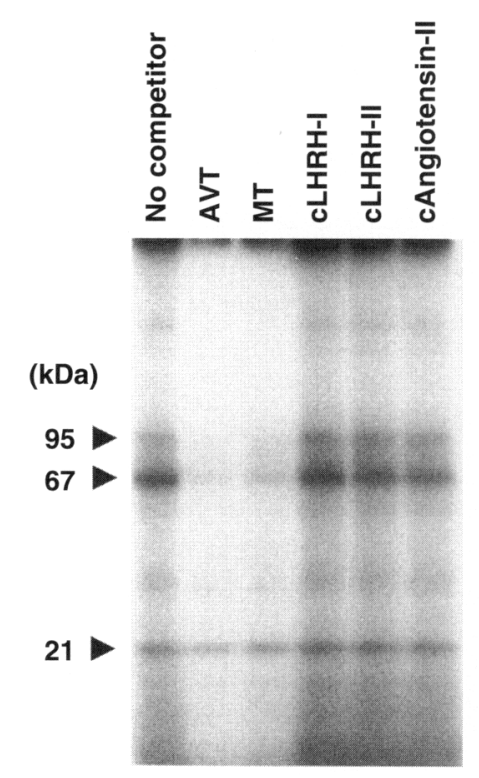

(b)

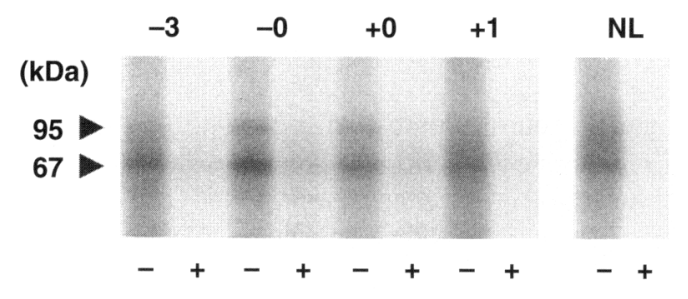

Fig. 1. Autoradiography of SDS-PAGE of the membrane fraction of the uterine myometrium of laying and nonlaying hens. (a) Competition in laying hens $5 \mathrm{~min}$ before oviposition. AVT: arginine vasotocin; MT: mesotocin; CLHRH-I: chicken luteinizing hormonereleasing hormone-I, Gln ${ }^{8}-\mathrm{GnRH}$; cLHRH-II: $\mathrm{His}^{5}, \mathrm{Trp}^{7}, \mathrm{Tyr}^{8}-\mathrm{GnRH}_{\text {; }}$ cAngiotensin-II: $\mathrm{Val}^{5}$-angiotensin-II. (b) Laying hens at different times ( -3 : $3 \mathrm{~h}$ before oviposition, -0 : within $5 \mathrm{~min}$ before oviposition, +0 : within $5 \mathrm{~min}$ after oviposition, $+1: 1 \mathrm{~h}$ after oviposition) and non-laying hens (NL). - : Without unlabelled AVT; +: with unlabelled AVT.

( $P \leq$ 0.05), Tukey's multiple range test (Tukey, 1953) was used to compare means of five groups in the present study.

\section{Results}

Three distinct dense bands were observed in the autoradiogram of SDS-PAGE after cross-linking of [125 I]-labelled AVT in the membrane fraction of the uterus of laying hens within $5 \mathrm{~min}$ before oviposition (Fig. 1a). The apparent molecular mass of 
Table 1. Molecular size, equilibrium dissociation constant $\left(K_{\mathrm{d}}\right)$ and maximum binding capacity $\left(B_{\max }\right)$ of arginine vasotocin (AVT) receptor of the uterine myometrium in laying hens before and after oviposition , and in nonlaying hens

\begin{tabular}{|c|c|c|c|c|c|}
\hline \multirow[b]{2}{*}{ Hen } & \multirow{2}{*}{$\begin{array}{l}\text { Time }(h) \text { before }(-) \text { and } \\
\text { after }(+) \text { oviposition }\end{array}$} & \multicolumn{2}{|c|}{ Molecular mass } & \multirow{2}{*}{$\begin{array}{c}K_{d} \\
\left(\mathrm{nmol} \mathrm{l}^{-1}\right)\end{array}$} & \multirow{2}{*}{ (pmol mg ${ }^{B_{\max }}$ protein) } \\
\hline & & $67 \mathrm{kDa}$ & $95 \mathrm{kDa}$ & & \\
\hline \multirow[t]{4}{*}{ Laying } & -3 & + & ND & $0.83 \pm 0.06^{b}$ & $2.89 \pm 0.11^{\mathrm{d}}$ \\
\hline & -0 (within $5 \mathrm{~min}$ ) & + & + & $0.50 \pm 0.02^{\mathrm{a}}$ & $0.92 \pm 0.03^{b}$ \\
\hline & +0 (within $5 \mathrm{~min}$ ) & + & + & $0.34 \pm 0.03^{\mathrm{a}}$ & $0.39 \pm 0.01^{\mathrm{a}}$ \\
\hline & $+I$ & + & $\mathrm{ND}$ & $0.88 \pm 0.03^{b}$ & $1.96 \pm 0.04^{c}$ \\
\hline Nonlaying & - & + & ND & $0.90 \pm 0.02^{b}$ & $1.78 \pm 0.02^{\mathrm{c}}$ \\
\hline
\end{tabular}

The value of molecular size represents the mean of four birds. The same samples were assayed for $\left[{ }^{225}[]\right.$-labelled AVT binding. + : detectable; ND: not detectable. The $K_{\mathrm{d}}$ and $B_{\max }$ values obtained by Scatchard analysis are the means $\leqslant$ sFM of four birds. Values with different letters are significantly different $(P<0.01)$.

the three bands was estimated to be 21,67 and $95 \mathrm{kDa}$, respectively. When a 10000 -fold molar excess of unlabelled AVT was present together with the $\left[{ }^{125} \mathrm{I}\right]$-labelled AVT in the cross-linking, the density of 67 and $95 \mathrm{kDa}$ bands was reduced but not of $21 \mathrm{kDa}$ band. The amount of ${ }^{125} \mathrm{I}$-labelled AVT binding in the $67 \mathrm{kDa}$ band, calculated from the value of the photo-stimulated luminescence of the Bio-Imaging Analyzer, was $1.42 \mathrm{fmol}$ in the absence of unlabelled AVT or MT, $0.27 \mathrm{fmol}$ in the presence of unlabelled AVT, and $0.63 \mathrm{fmol}$ in the presence of unlabelled MT, respectively. In the $95 \mathrm{kDa}$ band, it was $0.61 \mathrm{fmol}$ in the absence of unlabelled AVT or MT, $0.11 \mathrm{fmol}$ in the presence of unlabelled AVT, and $0.25 \mathrm{fmol}$ in the presence of unlabelled MT. In the presence of cLHRH-I, cLHRH-II and cAngiotensin-II, the autoradiogram appeared to be the same as that in the absence of any competitor.

The $95 \mathrm{kDa}$ band was not observed in the membrane fraction of the laying hen at $3 \mathrm{~h}$ before oviposition and at $1 \mathrm{~h}$ after oviposition, and also not in the nonlaying hen (Fig. Ib).

The $K_{\mathrm{d}}$ and $B_{\max }$ values of unseparated receptors were smaller in the hens within $5 \mathrm{~min}$ before or after oviposition than in the hens $3 \mathrm{~h}$ before or $1 \mathrm{~h}$ after oviposition, and also than in the nonlaying hens (Table 1 ).

\section{Discussion}

Among the three bands observed in the autoradiogram, the $67 \mathrm{kDa}$ and $95 \mathrm{kDa}$ bands may be the AVT receptor and the other band of $21 \mathrm{kDa}$ may be non-specific binding component to $\left[{ }^{125} \mathrm{I}\right]$-labelled AVT, because both $67 \mathrm{kDa}$ and $95 \mathrm{kDa}$ bands were reduced by the presence of unlabelied AVT but the $21 \mathrm{kDa}$ band was not. Both bands were reduced also by the presence of unlabelled MT, but the reduction as estimated by the density measurement was greater in the presence of AVT than in the presence of MT. The reduction was similar to our earlier findings in binding experiments (Takahashi et al., 1992). The existence of receptors having two molecular sizes is known in the uterus of rabbits on oxytocin receptors in which the molecular size is 50 and $65 \mathrm{kDa}$ (Hinko et al., 1992). The $95 \mathrm{kDa}$ AVT receptor may appear only at the time of oviposition in the laying hen, because the receptor of this molecular size was not found at $3 \mathrm{~h}$ before oviposition and $\mathrm{Ih}$ after oviposition in the laying hen and at a time in the nonlaying hen (Fig. Ib). The appearance of the larger molecular sized AVT receptor may be the cause of the increase in the binding affinity (decrease in the $K_{d}$ value) of unseparate AVT receptors at the time of oviposition found in the present study as in our earlier findings (Takahashi et al., 1994). In the mammalian uterus, neither the change in the binding affinity of receptor for oxytocin nor the appearance of new receptor of different molecular size at parturition has been reported. In the hen uterus, minor contractions of uterine muscles are observable during the period when there is an egg in the uterus, and the contraction increases markedly just before oviposition (Shimada and Asai, 1978). It seems likely that the two AVT receptors may control the phased contraction of the uterus in the hen.

\section{References}

Amemiya $Y$ and Miyahara J (1988) Imaging plate illuminates many fields Nature 336 89-90

Brennan WA (1988) Developmental aspects of the rat brain insulin receptor: loss of sialic acid and fluctuation in number characterize fetal development Endocrinology 122 2364-2370

Bruno JF and Berelowitz M (1989) Covalent labeling of the somatostatin receptor in rat anterior pituitary membranes Endocrinology 124 831-837

Fuji Technical Information (1993) Characteristic response of the imaging plate BAS Technical Information No. 2. Fuji Photo Film Co., Ltd, Tokyo, Japan

Hinko A, Soloff MS and Potier M (1992) Molecular size characterization of oxytocin receptors in rabbit amnion Endocrinology $1303554-3559$

Laemmli UK (1970) Cleavage of structural proteins during the assembly of the head of bacteriophage T4 Nature 227 680-685

Lowry OH, Rosebrough NJ, Farr AL and Randall RJ (1951) Protein measurement with the Folin phenol reagent Journal of Biological Chemistry 193 265-275

Munsick RA, Sawyer WH and van Dyke HB (1960) Avian neurohypophysial hormones: pharmacological properties and tentative identification Endocrinology 66 860-871

Rosenfeld RG, Pham H, Oh Y and Ocrant I (1989) Characterization of insulin-like growth factor-binding proteins in cultured rat pituitary cells Endocrinology 124 2867-2874

Rzasa J and Ewy Z (1970) Effect of vasotocin and oxytocin on oviposition in the hen Journal of Reproduction and Fertility 21 549-550

Scatchard G (1949) The attractions of proteins for small molecules and ions Annals of the New York Academy of Sciences 51 660-672

Shimada K and Asai I (1978) Uterine contraction during the ovulatory cycle of the hen Biology of Reproduction 19 1057-1062

Shodono M, Nakamura T, Tanabe $Y$ and Wakabayashi K (1975) Simultaneous determinations of estradiol-17 $\beta$, progesterone and luteinizing hormone in 
the plasma during the ovulatory cycle of the hen Acta Endocrinologica 78 $565-573$

Snedecor GW and Cochran WG (1967) One-way classifications. Analysis of variance. In Statistical Methods pp 258-298 Eds GW Snedecor and WG Cochran. The Iowa State University Press, Ames

Sonoda M, Takano M, Miyahara J and Kato H (1983) Computed radiography utilizing scanning laser stimulated luminescence Radiology 148 833-838

Swedlund AP and Rosenzweig SA (1990) Characterization of vasoactive intestinal peptide receptors in retina Experimental Eye Research 51 317-323
Takahashi T, Kawashima M, Kamiyoshi M and Tanaka K (1992) Arginine vasotocin binding component in the uterus (shell gland) of the chicken Acta Endocrinologica 127 179-184

Takahashi T, Kawashima M, Kamiyoshi M and Tanaka K (1994) Arginine vasotocin receptor binding in the hen uterus (shell gland) before and after oviposition European Journal of Endocrinology 130 366-372

Tukey JW (1953) Some selected quick and easy methods of statistical analysis Transactions-New York Academy of Sciences, Series II 16 88-97 